$\underline{\text { Research Article }}$

\title{
Relationship among Sexual Knowledge, Sexual Attitudes, and Sexual Behavior of Junior High School Students in West Jakarta
}

\section{Hubungan Pengetahuan Seksual dan Sikap Seksual dengan Perilaku Seksual pada Siswa SMP di Jakarta Barat}

\author{
Putra Brillian $D^{1}$, Francisca Tjhay ${ }^{2}$, Surilena Hasan ${ }^{3}$, Nelly Tina $W^{4}$ \\ ${ }^{1}$ School of Medicine and Health Sciences Atma Jaya Catholic University of Indonesia \\ ${ }^{2}$ Department of Medical Biology School of Medicine and Health Sciences Atma Jaya Catholic University of Indonesia \\ ${ }^{3}$ Department of Psychiatry and Behavioral Sciences School of Medicine and Health Sciences Atma Jaya Catholic \\ University of Indonesia \\ ${ }^{4}$ Department of Public Health and Nutrition School of Medicine and Health Sciences Atma Jaya Catholic University of \\ Indonesia
}

\begin{abstract}
Lack of sexual knowledge and increasing negative sexual attitudes in Indonesia could lead to risky sexual behavior. This problem increases teenage pregnancy, sexually transmitted infections, and abortion among adolescents. This study aimed to determine the relationship between sexual knowledge and sexual attitudes towards sexual behavior among junior high school students in West Jakarta. This study was cross-sectional, conducted on 544 junior high school students in West Jakarta. Measuring instruments used were characteristic questionnaires, sexual knowledge questionnaires, sexual attitude questionnaires, and sexual behavior questionnaires. Data analysis was performed using bivariate (chi-square). This study shows $79.2 \%$ of the respondents had low sexual knowledge, $45.6 \%$ respondents had negative sexual behavior, and $48.2 \%$ respondents had risky sexual behavior. This study finds that most male respondents had low sexual knowledge (80.8\%), low sexual attitude (56.8\%), and "less-safe" risky sexual behavior (60.0\%), while "not-safe" risky sexual behavior (2.7\%) was found higher in female respondents. Bivariate analysis shows a significant relationship between sexual knowledge $(p=0.006 ; 95 \% O R=1.763 / 95 \% \mathrm{Cl}=1.151-2.698)$ and sexual attitude $(p=<0.001 ; 0 R=2.852$ / 95\% Cl=2.0124.043) towards sexual behavior. In conclusion, low sexual knowledge and negative sexual attitudes increase the risk of risky sexual behavior.
\end{abstract}

Keywords: Adolescent, attitude, behavior, knowledge, sexual

\begin{abstract}
ABSTRAK
Rendahnya pengetahuan seksual dan peningkatan sikap seksual negatif di Indonesia menyebabkan perilaku seksual berisiko. Hal tersebut merupakan masalah serius yang menyebabkan peningkatan insiden kehamilan usia muda, penularan infeksi menular seksual, dan aborsi. Penelitian ini memiliki tujuan untuk mengetahui hubungan antara pengetahuan dan sikap seksual terhadap perilaku seksual pada siswa SMP di Jakarta Barat. Desain penelitian ini adalah studi potong lintang pada 544 siswa SMP di Jakarta Barat. Alat ukur yang digunakan merupakan kuesioner karakteristik, kuesioner pengetahuan seksual, kuesioner sikap seksual, dan kuesioner perilaku seksual yang di isi secara langsung oleh responden. Analisis data dilakukan secara deskriptif dan bivariat (chi-square). Hasil penelitian menunjukan terdapat $79,2 \%$ responden dengan pengetahuan seksual rendah dan $45,6 \%$ responden dengan perilaku seksual negatif dan $48,2 \%$ responden dengan perilaku seksual berisiko. Responden laki-laki terbanyak dengan pengetahuan seksual rendah (80,8\%), sikap seksual rendah (56,8\%), dan perilaku seksual berisiko kurang aman (60,0\%) sedangkan pada responden perempuan lebih banyak didapatkan perilaku seksual berisiko tidak aman (2,7\%). Analisis bivariat mendapatkan hubungan bermakna antara pengetahuan seksual $(p=0,006 ; O R=1,763 \mid 95 \% \mathrm{Cl}=1,151-2,698)$ dan $\operatorname{sikap}(\mathrm{p}=<0,001 ; \mathrm{OR}=2,852 \mid 95 \% \mathrm{Cl}=2,012$ 4,043 ) seksual terhadap perilaku seksual. Penelitian ini mendapatkan pengetahuan seksual yang rendah dan sikap seksual negatif meningkatkan risiko terjadinya perilaku seksual berisiko.
\end{abstract}

Kata Kunci: Pengetahuan, perilaku, remaja, sikap, seksual

Correspondence: Francisca Tjhay. School of Medicine and Health Sciences Atma Jaya Catholic University of Indonesia Jl. Pluit Raya no. 2, Jakarta Utara 14440 Tel. (021)6693168.6694366Email: francisca.tjhay@atmajaya.ac.id 


\section{INTRODUCTION}

Adolescence is a period of development transition marked by puberty (1). In this phase, adolescents experience brain development that receives new information, increasing sensitivity towards new stimuli that influence the reward pathway. Therefore, adolescents tend to have rewardseeking behavior which will makes adolescents easily influenced by the environment, peers, social media, and various other factors for risk-taking behavior (2-4).

In the last few years there have been an increase in risky sexual behavior among adolescents. Sexual behavior is an act and or expression of adolescents with their partners related to the reproductive process, which can be generally found at puberty $(3,5,6)$. Sexual behavior is also influenced by adolescent sexual scripts, including sexual attitudes and knowledge (7). Sexual behavior is considered risky if it can cause unwanted pregnancy, sexually transmitted infections, and mental-emotional disorders, such as depression and anxiety, among adolescents who are not mentally prepared to encounter sexual experiences $(5,7)$. Rusmiati and Hartono (2015) stated that one in four Indonesian teenagers have risky sexual behavior (8). Suwarni et al., obtained data on petting $(2.7 \%)$ and sexual intercourse $(13 \%)$, while Susanto et al., recorded the sexual behavior present in Indonesian adolescents are touching (39.2\%), kissing (13.3\%), and masturbation (13.9\%), while in which some of this behavior could lead to/result in various health risks in adolescents $(9,10)$. The enhancement of sexual behavior among adolescence trough out the years are visible by analyzing the results of periodic national surveys conducted by Survei Demografi Kesehatan Indonesia (SDKI) or Indonesian Health Demographic Survey that stated that the percentage of age of the first sexual intercourse in male and female have increase from the $59^{\text {th }}$ percentile on 2012 to the $74^{\text {th }}$ percentile on 2017, the majority of first age of sexual intercourse were 18-19 years old on 2012 and age 17-18 years old on $2017(11,12)$.

Sexual attitude is a subjective response of an adolescent towards reproduction health (3). Sexual attitude can be in the form of pride, privatization, viewpoint about sexual behavior consequences, and prevention (3). Positive sexual attitudes are a feeling of pride in maintaining selfesteem, having opinions about sexual behavior according to customs, and preventing risky-sexual behavior (5). A negative sexual attitude is where adolescents have a viewpoint of sexual behavior that is not according to traditions and does not acknowledge the consequences of sexual behavior and its prevention (5). Sexual attitude is affected by sexual knowledge, family relation, peers, sex, and religiosity (8). Changes towards sexual attitude may result from a shift in perceptions, methods of obtaining information, and social and cultural life that result in an increase of marital age and premarital sex due to globalization $(9,13)$. According to SDKI in 2007, 2012, and 2017 revealed an increase in the adolescents' prevalence who agreed on premarital sex and a decrease in the attitudes towards maintaining virginity $(11,12)$.

Sexual knowledge is the knowledge or perception of adolescents on reproductive health, sexual behavior, and changes during puberty $(3,9)$. Sexual knowledge shapes adolescents' attitudes towards their behavior to maintain their sexual health and well-being $(9,14)$. Sexual knowledge in Indonesia is still a taboo topic to be discussed. The data from Pusat data dan Informasi Kesehatan (InfoDATIN) or Center for Data and Health Information stated that most information on reproductive health in Indonesia originates from peers, whose validity cannot be assured (15). Lack of sexual knowledge will have an impact on the formation of negative sexual attitudes, which leads to risky sexual behavior among adolescents, such as touching, kissing, masturbation, petting, and sexual intercourse, and lead to unwanted pregnancy, abortion, and sexually transmitted infections $(5,8,15)$.

The phenomenon of risky sexual behavior in adolescents recently increases among adolescents within younger age such as Junior High School students in West Jakarta. While there are a lot of studies regarding sexual behavior among adolescent in High School age, the studies on Junior High School students are infrequent, therefore this study was conducted on Junior High School students in West Jakarta who are still in early adolescence where their cognitive development is not yet mature (15-17). This was the first study conducted on Junior High School students in West Jakarta regarding sexual behavior. Based on risky sexual behavior issues among early adolescents, it was essential to research the relationship between sexual knowledge and sexual attitudes towards sexual behavior in junior high school students in West Jakarta (15-17). This study aimed to find out the characteristic, sexual knowledge, sexual attitudes, and sexual behavior in junior high school students in West Jakarta and to determine their relationships.

\section{METHOD}

This study is descriptive-analytic with a cross-sectional approach that was conducted from July to November 2019. The respondents were junior high school students in West Jakarta who were active students from July 2019 to November 2019. A district consist of three schools in West Jakarta were selected by random sampling, however one of the schools denied the permission to collect data because the topic is considered taboo. The author then searches the nearest district (consist of 11 schools) and randomly picked one to replace one of the schools from the first district. The respondents were selected using stratified proportional random sampling where the sample were first categorized based on their level of education; class VII (year one), class VIII (year two), and class IX (year three).

The inclusion criteria in this study were Junior High School students who have given their consent to participate. Data were collected using self-reporting questionnaires consisting of a characteristic questionnaire, a sexual knowledge questionnaire, a sexual attitude questionnaire, and a sexual behavior questionnaire. The data were then extracted and processed statistically using univariate and bivariate test analysis using chi-square. Respondents with incomplete data set from the questionnaire were excluded from analysis.

Sexual knowledge and attitudes were assessed using a selfreporting questionnaire validated by Muflih and Syafitri in 2018, with Cronbach alpha 0.73 and 0,70 respectively. The sexual knowledge instrument contained 15 items measuring knowledge of the definition and knowledge of the consequences arising from sexual behavior. The questionnaire answers were measured using the Guttman scale with an assessment based on 0 and 1 point. The final value was determined low if the score was $75 \%$ (score $<11$ 
points) and high if the score was $75 \%$ (score $>11$ points) (5). The questionnaire measuring sexual attitude contained 15 items measuring feelings of pride, privatization, viewpoints of sexual behavior, consequences, and prevention. The questionnaire used a Likert scale, ranging from strongly agree (4), agree (3), disagree (2), and strongly disagree (1), and vice versa for questions with negative answers. The result of the assessment was negative if the score was 47 and positive if the score was $>47$ (5).

Sexual behavior was assessed using a self-reporting questionnaire validated by Muflih and Syafitri in 2018, with Cronbach alpha 0.89 . The questionnaire contained 15 items measured in a Likert scale, rated as "not risky" if the respondent answered all as "never" or category 0 on all items in the questionnaire and "risky" if there were one or more answers as "ever" or category 1 in the questionnaire. Further, risky sexual behavior was divided into two that were "less safe" if the respondent's answer involved touching, kissing, and masturbation (question 1-6, 8-10) and "not safe" if the respondent's answer involved deep kissing, oral sex, petting, and vaginal sex (question 7, 11-15) (5).

\section{RESULTS}

Characteristics, Sexual Knowledge, Sexual Attitudes, and Sexual Behavior of Junior High School Students in West Jakarta

As many as 544 junior high school students aged ranging from 10-18 years (average age of 13.5 years) were obtained using systematic random sampling. From there, $54 \%$ were female, $34.9 \%$ were year VII, 34.2\% were year VIII, and $30.9 \%$ were year IX students. There were $79.2 \%$ of respondents with low sexual knowledge, $45.6 \%$ of respondents with negative sexual attitudes, and $48.2 \%$ of respondents with risky sexual behavior (Table 1).

Table 1. Characteristics, sexual knowledge, sexual attitudes, and sexual behavior of Junior High School students in West Jakarta

\begin{tabular}{lr}
\hline \multicolumn{1}{c}{ Variable } & $\mathbf{n}(\%)$ \\
\hline Characteristics & $\begin{array}{r}\text { Range }=10-18 \\
\text { Mean }=13.5\end{array}$ \\
$-\quad$ Age & \\
- Gender & $250(46)$ \\
Male & $294(54)^{*}$ \\
Female & \\
- Education Level & $190(34.9)^{*}$ \\
Year VII & $186(34.2)$ \\
Year VIII & $168(30.9)$ \\
Year IX & \\
- Sexual Knowledge & $113(20.8)$ \\
High & $431(79.2)^{*}$ \\
Low & \\
- Sexual Attitude & $296(54.4)^{*}$ \\
Positive & $248(45.6)$ \\
Negative & \\
- Sexual Behavior & $282(51.8)^{*}$ \\
Not risky & $262(48.2)$ \\
Risky & $249(45.8)$ \\
Less safe & $13(2.4)$ \\
Not safe &
\end{tabular}

Note: *highest percentage

Description of Knowledge, Behavior, and Sexual Attitudes of Junior High School Students in West Jakarta Based on Gender and Education Level
Most of the male respondents had low sexual knowledge $(80.8 \%)$, negative sexual attitudes (56.8\%), and less safe sexual behavior (risky) (60\%). In contrast, unsafe risky sexual behavior was more common among female respondents, which was $2.7 \%$ (Table 2). Low sexual knowledge was found in respondents in year VIII (81.7\%), year IX (81.0\%), and year VII (75.3\%). This study also found negative sexual attitudes in year IX students (50.6\%), year VIII students (44.6\%), and year VII students (42.1\%). There was also more common risky sexual behavior, which were less safe $(55.4 \%)$ and not safe $(3.6 \%)$ in year IX respondents (Table 2).

Table 2. Description of knowledge, behavior, and sexual attitudes of Junior High School students in West Jakarta based on gender and education level

\begin{tabular}{|c|c|c|c|c|c|}
\hline \multirow{3}{*}{ Variable } & \multicolumn{5}{|c|}{ Junior High School Students Sexual Characteristics } \\
\hline & \multicolumn{2}{|c|}{ Gender } & \multicolumn{3}{|c|}{ Education Level } \\
\hline & $\begin{array}{l}\text { Male } \\
\mathrm{n}(\%)\end{array}$ & $\begin{array}{c}\text { Female } \\
\mathrm{n}(\%)\end{array}$ & $\begin{array}{c}\text { Year VII } \\
\text { n(\%) }\end{array}$ & $\begin{array}{c}\text { Year VIII } \\
\text { n(\%) }\end{array}$ & $\begin{array}{c}\text { Year IX } \\
\text { n(\%) }\end{array}$ \\
\hline \multicolumn{6}{|l|}{$\begin{array}{l}\text { Sexual } \\
\text { Knowledge }\end{array}$} \\
\hline - High & $48(19.2)$ & $65(22.1)^{*}$ & $47(24.7)^{*}$ & $34(18.3)$ & $32(19.0)$ \\
\hline - Low & $202(80.8)^{*}$ & $229(77.9)$ & $143(75.3)$ & $152(81.7)^{*}$ & $136(81.0)$ \\
\hline $\begin{array}{l}\text { Sexual } \\
\text { Attitude }\end{array}$ & & & & & \\
\hline - Positive & $108(43.2)$ & $188(63.9)^{*}$ & $110(57.9)^{*}$ & $103(55.4)^{*}$ & $83(49.4)$ \\
\hline - Negative & $142(56.8)^{*}$ & $106(36.1)$ & $80(42.1)$ & $83(44.6)$ & $85(50.6)^{*}$ \\
\hline $\begin{array}{l}\text { Sexual } \\
\text { Behavior }\end{array}$ & & & & & \\
\hline - Not risky & $95(38.0)$ & $187(63.6)^{*}$ & $122(64.2)^{*}$ & $91(48.9)$ & $69(41.1)$ \\
\hline - Risky & $155(62.0)^{*}$ & $107(36.4)$ & $68(35.8)$ & $95(51.1)$ & $99(58.9)^{*}$ \\
\hline - Less safe & $150(60.0)^{*}$ & 99 (33.7) & 64 (33.7) & $92(49.5)$ & $93(55.4)^{*}$ \\
\hline - Not safe & $5(2.0)$ & $8(2.7)^{*}$ & $4(2.1)$ & $3(1.6)$ & $6(3.6)^{*}$ \\
\hline
\end{tabular}

Note: *highest percentage

The Correlation between Knowledge and Sexual Attitudes toward Sexual Behavior of Junior High School Students in West Jakarta

This study indicated a significant relationship between knowledge $(p=0.006 ; 95 \%$ OR=1.763 |95\% Cl=1.1512.698) and sexual attitudes $(p=<0.001 ; O R=2.852 \mid 95 \%$ $\mathrm{Cl}=2.012-4.043$ ) towards sexual behavior among junior high school students in West Jakarta (Table 3).

\section{DISCUSSION}

Characteristics, Sexual Knowledge, Sexual Attitudes, and Sexual Behavior of Junior High School Students in West Jakarta

This study reveals that $54 \%$ of respondents are female. Data from the Ministry of Education and Culture (Kementerian Pendidikan dan Budaya) in the school year of 2018/2019 stated that there were more male students $(5,173,914$ people) than females $(4,951,810$ people) in Indonesia. Research conducted by Susanto et al., and Suwarni et al., in Indonesia obtained female samples of $55.5 \%$ and $53 \%$, respectively. The difference in this data could be because of the difference in time when taking the sampling $(9,10,18)$.

The study shows $79.2 \%$ of respondents with low sexual knowledge. The result of this study is consistent with the results from the research by Romulo on early adolescence in Banjarmasin that $88.68 \%$ of respondents are with mid to 
Table 3. The Correlation between knowledge and sexual attitudes toward sexual behavior of Junior High School students in West Jakarta

\begin{tabular}{|c|c|c|c|c|c|c|c|c|c|}
\hline & \multicolumn{9}{|c|}{ Junior High School Students in West Jakarta } \\
\hline & \multicolumn{4}{|c|}{ Sexual Behavior } & \multirow{3}{*}{ Total } & \multirow{3}{*}{ p-value } & \multirow{3}{*}{ OR } & & \\
\hline & \multicolumn{2}{|c|}{ Not risky } & \multicolumn{2}{|c|}{ Risky } & & & & \multicolumn{2}{|c|}{$95 \% \mathrm{Cl}$} \\
\hline & $\mathbf{n}$ & $\%$ & $\mathbf{n}$ & $\%$ & & & & Low & High \\
\hline Sexual Knowledge $^{* *}$ & & & & & & 0.006 & 1.763 & 1.151 & 2.698 \\
\hline High & 71 & $(62.8)^{*}$ & 42 & $(37.2)$ & 113 & & & & \\
\hline Low & 211 & $(49.0)$ & 220 & $(51.0)^{*}$ & 431 & & & & \\
\hline Total & 282 & & 262 & & 544 & & & & \\
\hline Sexual Attitude ${ }^{* *}$ & & & & & & $<0.001$ & 2.852 & 2.012 & 4.043 \\
\hline Positive & 188 & $(63.5)^{*}$ & 108 & (36.5) & 296 & & & & \\
\hline Negative & 94 & (37.9) & 154 & $(62.1)^{*}$ & 248 & & & & \\
\hline Total & 282 & & 262 & & 544 & & & & \\
\hline
\end{tabular}

Note: *highest percentage, ${ }^{* *} p$-value $<0.05$

low sexual knowledge (19). Adolescents with low sexual knowledge do not have a deep understanding of reproductive health, sexual behavior, and changes in puberty; this knowledge will form the mindset that creates the sexual attitude of the teenager $(3,5)$. Sexual knowledge is one of the protective factors that can delay the onset of first sexual intercourse, increasing the usage of condoms to prevent risky sexual behavior $(7,9,14)$. Low sexual knowledge can cause teens to engage in risky sexual behavior without knowing the consequences.

The results of this study showed that $45.6 \%$ of respondents possess negative sexual attitudes. This result is consistent with the research by Suwarni et al., in Pontianak that found $45.3 \%$ of respondents with negative sexual attitudes (10). Sexual attitude is a response owned by individuals regarding reproductive health, and an increase in negative sexual attitudes among adolescents is caused by a shift or change in perception, culture, social life, and the development of information technology $(3,5,13)$. Sexual attitudes of adolescents determine the choice of sexual partners and behavior; thus, negative sexual attitudes in adolescents can cause risky sexual behavior, such as early sexual intercourse, multiple sex partners, and lack of contraception use $(8,13,20)$. In addition to sexual knowledge, factors of religiosity, parental supervision, peers, and drug abuse also play a role in forming the sexual attitudes among adolescents $(9,10,21,22)$.

This study shows $48.2 \%$ of respondents have risky sexual behavior. In details, $45.8 \%$ of respondents have less safe risky sexual behavior (touching, kissing, and masturbation) and $2.4 \%$ have not safe risky sexual behavior (deep kissing, oral sex, petting, and vaginal sex). Research by Susanto et al., in East Java showed that there were $50.6 \%$ of teenagers who have less safe risky sexual behaviors (9). Research by Suwarni et al., showed $9 \%$ risky sexual behavior (10). Research by Leerlooijer et al., found that as many as $3.8 \%$ of respondents have done sexual intercourse (23). Risky sexual behaviors can cause various reproductive health problems, such as an increase in unwanted pregnancies, abortion rate, the prevalence of STIS (HIV-AIDS), maternal and child mortality, abortion, and mental-emotional disorder. This study has a difference in the figure compared to research by Susanto et al., Suwarni et al., and Leerlooijer et al., the difference can be caused by differences in the age and educational level of the respondent, interaction among adolescents, the local culture, and stigma and taboo related to sexual topics in Indonesia $(9,10,23,24)$.

Description of Knowledge, Behavior, and Sexual Attitudes of Junior High School Students in West Jakarta Based on Gender and Education Level

This study shows that low sexual knowledge (80.8\%), negative sexual attitudes (56.8\%), and risky sexual behavior (62.0\%) are more common in males rather than in female respondents. Many aspects can influence the formation of knowledge, attitudes, and behavior in adolescents, one of which is family relationships. Research by Suwarni et al. (2015) states that an ineffective relationship between parents and adolescents can increase the risk of adolescents to obtain negative influences from their peers (10). InfoDATIN states that adolescent information about reproductive health in Indonesia comes from their peers, in which the truth cannot be guaranteed (15). Research by Suwarni et al., shows that male adolescents have more distant relationships with their parents than female adolescents so that peers would more easily influence sexual knowledge, sexual attitudes, and sexual behavior of male adolescents (10). Although female adolescents have a closer relationship with their parents, discussion on sexual health among parents and adolescents is still regarded as taboo in Indonesia. This condition is worsened by the number of pictures and games on the internet that could result in increased pornography consumption in Indonesia. Therefore, the prevalence of risky sexual behavior is still quite high among female respondents $(36.4 \%)$ in this study (25). In addition to parental relationships, negative sexual attitudes and risky behavior can also be caused by immature puberty where the risk of risk-taking behavior is higher. A higher prevalence of risky sexual behavior can also be caused by a slower onset of male puberty (10-17 years) than that in women (9-14 years) $(26,27)$.

This study shows that the prevalence of not safe risky sexual behavior is more common in female respondents $(2.7 \%)$ than in males $(2.0 \%)$. Research by Tadesse and Yakob stated that the initiation of risky sexual behavior outside the marriage among female adolescents could be due to curiosity, the influence of friends, money offered by men, coercion from partners, and drug abuse (28). Research in Malaysia shows that despite protective factors from parental supervision, which are common in female adolescents, risky sexual behavior in adolescent girls still occurs due to factors such as coercion from partners, juvenile delinquency, and negative sexual attitudes 
$(29,30)$. This study also shows values of percentage of knowledge, attitudes, and sexual behavior that do not differ significantly between respondents in year VII, VIII, and IX. It may be due to respondents that are in the same age group.

The Correlation between Knowledge and Sexual Attitudes toward Sexual Behavior of Junior High School Students in West Jakarta

Bivariate analysis shows a significant relationship between knowledge $(p=0.006 ; 95 \%$ OR=1.763 |95\% $\mathrm{Cl}=1.151-2.698)$ and sexual attitudes $(p=<0.001$; $\mathrm{OR}=2.852$ | $95 \% \mathrm{Cl}=2.012-4.043$ ) to the sexual behavior of junior high school students in West Jakarta. The analysis also shows that adolescents with low sexual knowledge are 1.763 times more likely to have a risky sexual behavior, and adolescents with negative sexual attitudes are 2.852 times more likely to have risky sexual behavior compared to adolescents with high sexual knowledge and positive sexual attitudes. The results of this study are in accordance with research conducted by Suwarni et al., that there is a relationship between sexual attitudes and intentions and risky sexual behavior with $p=0.0001$, and research by Susanto et al., that showed a relationship

\section{REFERENCES}

1. Meeus W. Adolescent Psychosocial Development: A Review of Longitudinal Models and Research. Developmental Psychology. 2016; 52(12): 1969-1993.

2. Vijayakumar N, Op de Macks Z, Shirtcliff EA, and Pfeifer JH. Puberty and the Human Brain: Insights Into Adolescent Development. Neuroscience and Biobehavioral Reviews. 2018; 92: 417-436.

3. Sakurai $T$ and Gamo NJ. Cognitive Functions Associated with Developing Prefrontal Cortex During Adolescence and Developmental Neuropsychiatric Disorders. Neurobiology of Disease. 2018; 131: 1-16.

4. Flannery JE, Giuliani NR, Flournoy JC, and Pfeifer JH. Neurodevelopmental Changes Across Adolescence in Viewing and Labeling Dynamic Peer Emotions. Developmental Cognitive Neuroscience. 2017; 25: 113-127.

5. Prendergast LE, Toumbourou JW, McMorris BJ, and Catalano RF. Outcomes of Early Adolescent Sexual Behavior in Australia: Longitudinal Findings in Young Adulthood. Journal of Adolescent Health. 2019; 64(4): 516-522.

6. Muflih M and Syafitri EN. Perilaku Seksual Remaja dan Pengukurannya dengan Kuesioner. Jurnal Keperawatan Respati Yogyakarta. 2018; 5(3): 438443.

7. Baams L, Dubas JS, Overbeek G, and van Aken MAG. Transitions in Body and Behavior: A Meta-Analytic Study on the Relationship Between Pubertal Development and Adolescent Sexual Behavior. The Journal of Adolescent Health: Official Publication of the Society for Adolescent Medicine. 2015; 56(6): 586-598.

8. Rusmiati D and Hastono SP. Sikap Remaja terhadap Keperawanan dan Perilaku Seksual dalam Berpacaran. Kesmas: Jurnal Kesehatan Masyarakat between reproductive health knowledge and sexual behavior with $p=0.008$ and sexual attitude towards sexual behavior with $p<0.001(9,10)$. Sexual behavior is one factor that shapes sexual attitudes, so sexual knowledge is not directly related to sexual behavior $(9,14)$. The high prevalence of sexual knowledge, sexual attitudes, and risky sexual behavior in this study show the importance of preventive, curative, and rehabilitative efforts in adolescents in Jakarta to reduce the level of risky sexual behavior and its complications.

In conclusion, low sexual knowledge and negative sexual attitudes are consistent with increase in risky sexual behavior. The author suggests increasing the awareness of the importance of sexual education on early Junior High School Age by parents and teachers to prevent low sexual knowledge and negative sexual attitudes among early adolescence.

\section{ACKNOWLEDGEMENT}

The authors would like to acknowledge all educational institutions and junior high school students who took part in this study and all parties who have provided support, cooperation, and assistance during the study.

Nasional. 2015; 10(1): 29-36.

9. Susanto T, Rahmawati I, Wuryaningsih EW, et al. Prevalence of Factors Related to Active Reproductive Health Behavior: A Cross-Sectional Study Indonesian Adolescent. Epidemiology and Health. 2016; 38: 110.

10. Suwarni L, Ismail D, Prabandari YS, and Adiyanti M. Perceived Parental Monitoring on Adolescence Premarital Sexual Behavior in Pontianak City, Indonesia. International Journal of Public Health Science (IJPHS). 2015; 4(3): 211-219.

11. BKKBN, BPS, Kementerian Kesehatan RI, and USAID. Survei Demografi dan Kesehatan Indonesia 2012. Jakarta: BPS; 2012.

12. BKKBN, BPS, Kementerian Kesehatan RI, and USAID. Survei Demografi dan Kesehatan Indonesia 2017. Jakarta: BPS; 2018

13. Techasrivichien T, Darawuttimaprakorn N, Punpuing $\mathrm{S}$, et al. Changes in Sexual Behavior and Attitudes Across Generations and Gender Among a Population-Based Probability Sample from an Urbanizing Province in Thailand. Archives of Sexual Behavior. 2016; 45(2): 367-382.

14. Young H, Long SJ, Hallingberg B, et al. School Practices Important For Students' Sexual Health: Analysis of The School Health Research Network Survey In Wales. European Journal of Public Health. 2018; 28(2):309-314.

15. Young $\mathrm{H}$, Long SJ, Hallingberg B, et al. School Practices Important for Students' Sexual Health: Analysis of the School Health Research Network Survey in Wales. European Journal of Public Health. 2018; 28(2): 309-314.

16. Kawuwung SP. Terkait Kasus Chat Asusila, KPAl dan Polisi akan Datangi SMPK Penabur. (Online) 2017. https://www.harianindo.com/2017/08/14/221058/ terkait-kasus-chat-asusila-kpai-dan-polisi-akan- 
datangi-smpk-penabur/

17. Tim KPAI. KPAl: Sisi Lain Modus Prostitusi Anak, Dipacari Lalu Dijual. (Online) 2020. https://www.kpai.go.id/publikasi/kpai-sisi-lainmodus-prostitusi-anak-dipacari-lalu-dijual

18. Pusat Data dan Statistik Pendidikan. Tabel Statistik Sekolah Menengah Pertama. (Online) 2019. http://statistik.data.kemdikbud.go.id/index.php/pa ge/smp

19. Romulo HM, Akbar SN, and Mayangsari MD. Peranan Pengetahuan Kesehatan Reproduksi terhadap Perilaku Seksual Remaja Awal. Jurnal Ecopsy. 2016; 1(4): 1-6.

20. McElwain AD, Kerpelman JL, and Pittman JF. The Role of Romantic Attachment Security and Dating Identity Exploration in Understanding Adolescents' Sexual Attitudes and Cumulative Sexual Risk-Taking. Journal of Adolescence. 2015; 39: 70-81.

21. Azinar M. Perilaku Seksual Pranikah Berisiko terhadap Kehamilan Tidak Diinginkan. KEMAS: Jurnal Kesehatan Masyarakat. 2013; 8(2): 153-160.

22. Simak VF, Fitriyani $P$, and Setiawan $A$. The Relationships Between Risky Sexual Practices and Spiritual Intelligence of Adolescents In Indonesia. Comprehensive Child and Adolescent Nursing. 2019; 42(1): 73-81.

23. Leerlooijer JN, Ruiter RAC, Damayanti R, et al. Psychosocial Correlates of The Motivation To Abstain From Sexual Intercourse Among Indonesian Adolescents. Tropical Medicine \& International Health. 2014; 19(1): 74-82.
24. Theresia F, Tjhay F, Surilena S, and Tina Widjaja N. Faktor-faktor yang Mempengaruhi Perilaku Seksual Siswa SMP di Jakarta Barat. Jurnal Kesehatan Reproduksi. 2020; 11(2): 101-113.

25. Hald GM and Mulya TW. Pornography Consumption and Non-Marital Sexual Behaviour in a Sample of Young Indonesian University Students. Culture, Health, \& Sexuality. 2013;15(8):981-96.

26. Bagnell AL. Approaching the Adolescent. In: Goldbloom RC (Ed). Pediatric Clinical Skills 4th ed. Philadelphia: Elsevier/Saunders; 2011: p. 258-264.

27. Susanto $\mathrm{T}$, Saito $\mathrm{R}$, Syahrul, et al. Immaturity in Puberty and Negative Attitudes Toward Reproductive Health among Indonesian Adolescents. International Journal of Adolescent Medicine and Health. 2016; 30(3):1-11.

28. Tadesse G and Yakob B. Risky Sexual Behaviors Among Female Youth In Tiss Abay, A Semi-Urban Area Of The Amhara Region, Ethiopia. PLoS One. 2015; 10(3): 1-16.

29. Ahmad N, Awaluddin SM, Ismail H, Samad R, and NikAbdRashid N. Sexual Activity Among Malaysian School-Going Adolescents: What are the Risk and Protective Factors? Asia-Pacific Journal of Public Health. 2014; 26(5 Suppl): 44S-52S.

30. Ahmadian M, Hamsan $\mathrm{HH}$, Abdullah $\mathrm{H}$, Samah AA, and Noor AM. Risky Sexual Behavior among Rural Female Adolescents in Malaysia: A Limited Role of Protective Factors. Global Journal of Health Science. 2014; 6(3): 165-174. 